\title{
Flora of Public Squares in the City of Areia, Paraíba, Brazil
}

\author{
Azenate Campos Gomes $^{1}$ (D), Lucimara Ferreira de Figueredo ${ }^{2}$ (D), \\ José Thyago Aires Souza ${ }^{2}$ (D), Jacob Silva Souto ${ }^{3}$ (D), \\ Alecksandra Vieira de Lacerda ${ }^{4}$ (D) \\ ${ }^{1}$ Universidade Federal da Paraíba (UFPB), João Pessoa, PB, Brasil \\ ${ }^{2}$ Universidade Federal da Paraíba (UFPB), Areia, PB, Brasil \\ ${ }^{3}$ Universidade Federal de Campina Grande (UFCG), Patos, PB, Brasil \\ ${ }^{4}$ Universidade Federal de Campina Grande (UFCG), Sumé, PB, Brasil
}

\begin{abstract}
Public squares are important spaces in the cities and stand out for providing improvements in the quality of urban life. Thus, this study aimed to carry out the floristic survey of public squares in the city of Areia, Paraíba state, Brazil, and analyze the similarity between their flora. The species classification was performed by consulting experts and through comparative morphology. The floristic similarity was calculated using the Jaccard index. Twenty-nine species distributed in 26 genera and 20 families were recorded. Stenotaphrum secundatum (Walter) Kuntze had the highest relative frequency $(8.52 \%)$. Sixty-three percent of the species are exotic and $28 \%$ contain toxic substances. There was a significant similarity (1) only between Tenente Juvenal Espíndola and Simeão Patrício squares. The data evidence the need for better planning of floristic composition of the squares in the city of Areia, as well as for a tree planting manual.
\end{abstract}

Keywords: floristic survey, landscaping, urban spaces. 


\section{INTRODUCTION AND OBJECTIVES}

Green areas in urban environments have as main characteristic the vegetation and permeable soil. Guzzo et al. (2006) state that these areas provide several benefits to the population such as noise and air pollution reduction, microclimate improvement and shelter for animals, which can be measured and evaluated, and contribute to the aesthetics of the city.

According to Eckert \& Mascaró (2015), valuing green areas in the cities is of fundamental importance and, therefore, it is necessary a quantitative definition of the areas to be preserved, conserved, transformed or reconstructed for the construction of pleasant environments. For Pivetta \& Silva Filho (2002), the definition of these areas, as well as the planning for the implementation of tree planting, does not depend on the size of the cities.

The economic and social benefits provided by trees in the cities is a logical process, which brings many ecological, biological and psychological benefits. However, Lira et al. (2004) claim that the accelerated expansion of cities, caused by the population growth, has compromised the quality of their free spaces and green areas. Soil impermeabilization, local climate change, and pollutant concentration are some factors responsible for this problem.

According to Angelis \& Angelis Neto (2000), squares are free and urban public spaces intended for leisure and conviviality of people. Although in almost all Brazilian cities and towns there are squares, parks and other areas where the population can have leisure time and enjoy the aesthetics of nature, most of them have no organized spaces, which become no more than a loose collection of open-air spaces.

For Barcellos et al. (2012), in the planning of floristic composition of squares, some criteria of extreme importance for the success of their implementation should be considered, for example: planting of species with pivoting root system; preference for native species occurring in the bioclimatic region, since they are adapted to the local ecosystem, which promotes their conservation; the shape and size of the plant's crown should be compatible with the available threedimensional physical space; and preference for species that produce small to medium-sized flowers and fruits.

Given the above, this study aimed to carry out the floristic survey the public squares of the city of
Areia, Paraíba state, Brazil, and analyze the similarity between their flora.

\section{MATERIALS AND METHODS}

Areia is located at the coordinates $68^{\circ} 57^{\prime} 48^{\prime \prime} \mathrm{S}$ and $35^{\circ} 41^{\prime} 30^{\prime \prime} \mathrm{W}$, at an altitude of $618 \mathrm{~m}$, in the Agreste mesoregion, specifically in the Brejo microregion, in the eastern of Paraíba, Brazil. The Agrest consists of 66 municipalities, grouped in eight microregions. The municipality has a population of 23,829 inhabitants distributed in $269,494 \mathrm{~km}^{2}$ (IBGE, 2010).

The climate of the region, according to the Köppen classification, is classified as As' (McKnight \& Hess, 2000), that is, tropical hot-humid, with a mean annual rainfall higher than 1,400 mm. Red Yellow Dystrophic Equivalent Argisols are the predominant soils in the region (Brasil, 1972).

The city is characterized by being in a mountainous region, in a transition area between the Atlantic forest and the Caatinga, with vegetation varying from the Caatinga itself to remnants of Atlantic forest (forest of Brejo) in the highest areas of the mountains. Its relief comprises deep valleys and dissected straits (Marques et al., 2014).

This research was carried out specifically in the public squares and in the boardwalk of the city of Areia. The study area comprised the João Pessoa, Dr. Cunha Lima, Solon de Lucena, and Ministro José Américo de Almeida squares and Calçadão João Cardoso, all downtown; the Praça do Trabalho, in Jussara neighborhood, the Tenente Juvenal Espíndola and Pedro Freire squares, in Pedro Perazzo neighborhood, and the Simeão Patrício Square, in Frei Damião neighborhood.

The activities were based on the analysis of the physical characteristics of the abovementioned public spaces, which were georeferenced using a GPS device. Their floristic composition was analyzed considering all cultivated plant habits.

The data from the floristic survey were confronted with the species characteristics, mainly regarding the classification based on the origin, presence of toxic substances, and root system (Lorenzi, 1998; 2000; 2002; Lorenzi \& Matos 2002; Souza \& Lorenzi, 2008; Mattos et al., 2011; Sinitox, 2009). 
For the classification of the species, photographic images were recorded in April 2014. The species were classified by consulting experts and through comparative morphology, using specialized bibliography. The species were organized according to their family in the APG III system (APG, 2009), including information about their habit.

The absolute and relative frequencies of all species were calculated and the number of young trees and shrubs was recorded. The specimens were divided into three height classes: $\leq 6 \mathrm{~m}$ (below the power distribution grid), $>6 \mathrm{~m}$ and $\leq 9.4 \mathrm{~m}$ (between the low-to-medium voltage grid), and $>9.4 \mathrm{~m}$ (above the medium voltage grid). The height was measured using a graduated ruler. The percentage of individuals, mechanical damage, conflict with the electric grid, and phytosanitary status were verified in each height class.

Mechanical damages were considered when the specimen had poor pruning, with no conditions of regrowth, cuts and cavities in the stem, and damages in the roots. In each specimen, it was verified if there were conflicts with the electricity distribution grid. Regarding the phytosanitary condition, those individuals with symptoms of diseases and with more than $50 \%$ of their aerial part and/or $30 \%$ of their stem circumference damaged were considered as diseased plants. Those with $50 \%$ or more of the aerial part attacked by insects were classified as plants attacked by plagues. The root system was evaluated as the presence or absence of damage to sidewalks and urban pavements.
The floristic similarity was calculated by the Jaccard index (similarity coefficient), which considers the relationship between the number of common species and the total number of species found when comparing two samples (Mueller-Dombois \& Ellenberg, 1974). This index was determined by Equation 1:

$$
J S=\frac{a}{a+b+c}
$$

JS: Jaccard similarity a: number of species common to both squares; $b$ : number of species exclusive to square $a$; c: number of species exclusive to square $b$.

\section{RESULTS AND DISCUSSION}

The city of Areia is constituted by 11 neighborhoods, but there are squares only downtown and in Jussara, Pedro Perazzo and Frei Damião neighborhoods, which account for nine squares of a relatively small area (Table 1). Calçadão João Cardoso comprises the largest area $\left(1780.40 \mathrm{~m}^{2}\right)$, followed by João Pessoa Square $\left(856.40 \mathrm{~m}^{2}\right)$, Ministro José Américo de Almeida Square, popularly known as Rosário Square $\left(746.30 \mathrm{~m}^{2}\right)$ and Solon de Lucena Square $\left(184.10 \mathrm{~m}^{2}\right)$. The areas of the other ones range from $12.80 \mathrm{~m}^{2}$ to $39.50 \mathrm{~m}^{2}$.

Most of the public squares are homogeneously located in the city, specifically downtown, except for Praça do Trabalho, in Jussara neighborhood, Simeão Patrício Square, in Frei Damião neighborhood, and Tenente Juvenal Espíndola and Pedro Freire squares, both in Pedro Freire neighborhood.

Table 1. Location of the public squares in the city of Areia, Paraíba, Brazil.

\begin{tabular}{lcccc} 
Square & \multicolumn{2}{c}{ Coordinates } & Altitude $\left(\mathbf{m}^{\prime}\right)$ & Area $_{\left(\mathbf{m}^{2}\right)}$ \\
\hline João Pessoa & S & W & & 856.40 \\
\hline Dr. Cunha Lima & $06^{\circ} 58^{\prime} 13.3^{\prime \prime}$ & $035^{\circ} 42^{\prime} 22.8^{\prime \prime}$ & 637 & 12.80 \\
\hline Solon de Lucena & $06^{\circ} 58^{\prime} 05.7^{\prime \prime}$ & $035^{\circ} 42^{\prime} 14.7^{\prime \prime}$ & 623 & 184.10 \\
\hline Ministro José Américo de Almeida & $06^{\circ} 58^{\prime} 06.8^{\prime \prime}$ & $035^{\circ} 42^{\prime} 03.6^{\prime \prime}$ & 629 & 746.30 \\
\hline Praça do Trabalho & $06^{\circ} 58^{\prime} 10.9^{\prime \prime}$ & $035^{\circ} 42^{\prime} 12.3^{\prime \prime}$ & 629 & 24.30 \\
\hline Tenente Juvenal Espíndola & $06^{\circ} 58^{\prime} 25.8^{\prime \prime}$ & $035^{\circ} 42^{\prime} 55.3^{\prime \prime}$ & 614 & 29.30 \\
\hline Pedro Freire & $06^{\circ} 57^{\prime} 78.5^{\prime \prime}$ & $035^{\circ} 42^{\prime} 19.4^{\prime \prime}$ & 608 & 39.50 \\
\hline Simeão Patrício & $06^{\circ} 57^{\prime} 81.5^{\prime \prime}$ & $035^{\circ} 42^{\prime} 24.9^{\prime \prime}$ & 611 & 19.20 \\
\hline Calçadão João Cardoso & $06^{\circ} 57^{\prime} 88.2^{\prime \prime}$ & $035^{\circ} 42^{\prime} 46.5^{\prime \prime}$ & 579 & 1780.40 \\
\hline
\end{tabular}


All squares have some type of vegetation; however, only João Pessoa, Solon de Lucena, and Ministro José Américo de Almeida squares and Calçadão João Cardoso have part of their area covered by grass. One of the problems identified in Dr. Cunha Lima was the high density of herbaceous plants, causing the death of other specimens, and the presence of invasive species such as Cyperus spp.

According to Gomes \& Soares (2003), most authors point out the negligence and lack of interest of public bodies and of the population itself in recognizing the importance of vegetation in urban space. Thereby, more in-depth investigations are necessary, especially relating to the conditions of the vegetation spatial distribution, since many of these spaces are degraded.

The floristic richness of the squares comprises 29 species, distributed in 26 genera and 20 families. Arboreal was the most representative habit (15 species), followed by the herbaceous (10 species) and shrub (four species) (Table 2).

Table 2. Floristic composition of the squares in the city of Areia, Paraíba, Brazil.

\section{Agavaceae}

$\begin{array}{lccc}\text { 1. Clorophytum comosum (Thunb.) } & \text { Grama } \\ \text { Jacques } & \text { paulistinha } & \times & \text { Her. } \\ \text { Exo. }\end{array}$

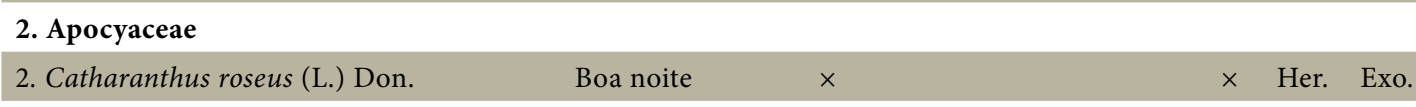

\section{Aracaceae}

\begin{tabular}{|c|c|c|c|c|}
\hline 3. Phoenix roebelenii O'Brien & $\begin{array}{l}\text { Tamareira de } \\
\text { Jardim }\end{array}$ & $x$ & $x$ & Shr. \\
\hline 4. Roystonea oleracea (Jacq.) Cook & $\begin{array}{c}\text { Palmeira } \\
\text { imperiana }\end{array}$ & $x$ & $\times$ & Arb. \\
\hline
\end{tabular}

4. Araucariaceae
5.Araucaria araucana (Mol.) K. Koch. Pinheiro

$\begin{array}{lcccc}\text { 5. Arestaceae } & & & & \\ \text { 6. Gaillardia } \mathrm{x} \text { grandiflora Van Hout.. } & \text { Flor geral } & \times & \text { Her. } & \text { Exo. } \\ \text { 7. Callistephus chinensis (L.) Ness } & \text { Celsa } & \times & \text { Her. } & \text { Exo. }\end{array}$

\section{Bignoniaceae}

\begin{tabular}{|c|c|c|c|}
\hline 8. Tabebuia sp 1. & Ipê roxo & $x$ & Arb. \\
\hline 9. Tabebuia sp 2. & Pau d'arco & $\times$ & Arb. \\
\hline $\begin{array}{l}\text { 10. Tabebuia umbellata (Sond.) } \\
\text { Sandwith }\end{array}$ & Ipê amarelo & $\times$ & Arb. \\
\hline 11. Tecomastans (L.) Juss. ex Kunth & Ipê de jardim & $\times$ & Arb. \\
\hline
\end{tabular}

\section{Burseraceae}

12. Protium heptaphyllum (Aubl.) March

Amescla $\quad \times$

Arb. Nat.

\section{Combretaceae}

13. Terminalia catappa L. Castanhola $\times \quad \times \quad$ Arb. Exo.

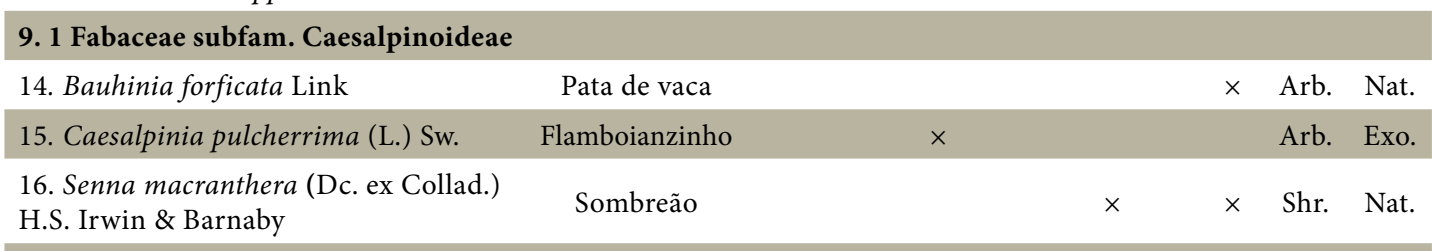


Table 2. Continued...

\section{Family Species}

\section{$\begin{array}{llllllllllll}\text { Ethnospecies } & \text { A } & \text { B } & \text { C } & \text { D } & \text { E } & \text { F } & \text { G } & \text { H } & \text { I } & \text { Hab. } & \text { Org. }\end{array}$}

\section{Lamiaceae}

$\begin{array}{llcl}\text { 18. Solenostemon scutellari Oids } & \text { Bredo } & \text { Her. } & \text { Exo. } \\ \text { 11. Malpighiaceae } & & & \end{array}$

\section{Meliaceae}

20. Azadirachta indica A. Juss $\quad$ Nim $\quad \times \quad$ Arb. Exo.

\section{Moraceae}

$\begin{array}{lcccc}\text { 21. Ficus benjamina L. } & \text { Ficus } & \times & \times & \text { Arb. Exo. } \\ \text { 22. Ficus nymphaeifolia Miller } & \text { Gameleira } & \times & \text { Arb. Nat. }\end{array}$

\section{Oxalidaceae}

23. Oxalis spiiralis Ruiz \& Pav. ex G. Don

Trevo

15. Poaceae
$\begin{aligned} & \text { 24. Stenotaphrum secundatum (Walter) } \\ & \text { Kuntze }\end{aligned} \begin{gathered}\text { Grama de } \\ \text { Santo } \\ \text { Agustinho }\end{gathered} \times \times \times \quad \times \quad$ Her. Nat.

\section{Portulaceae}

\begin{tabular}{|c|c|c|c|c|c|c|c|c|c|c|c|c|}
\hline 25. Portulaca oleraceae L. & Onze horas & $\times$ & & & & & & & & & Her. & Exo. \\
\hline \multicolumn{13}{|l|}{ 17. Rosaceae } \\
\hline 26. Rosa x grandiflora Hort. & Roseira & $x$ & & & & & & & & & Her. & Exo. \\
\hline \multicolumn{13}{|l|}{ 18. Rubiaceae } \\
\hline 27. Mussaenda alicia Hort. & Mussaenda & & & & $x$ & & & & & & Shr. & Exo. \\
\hline \multicolumn{13}{|l|}{ 19. Solanaceae } \\
\hline $\begin{array}{l}\text { 28. Brunfelsia pauciflora (Cham. \& } \\
\text { Schltdl.) Benth. }\end{array}$ & $\begin{array}{l}\text { Manacá de } \\
\text { Jardim }\end{array}$ & $\times$ & & & $\times$ & & & & & $\times$ & Shr. & Nat. \\
\hline \multicolumn{13}{|l|}{ 20. Verbenaceae } \\
\hline 29. Lantana camara L. & $\begin{array}{l}\text { Chumbinho } \\
\text { amarelo }\end{array}$ & & $x$ & $x$ & & & & & & & Her. & Nat. \\
\hline TOTAL & & 13 & 3 & 6 & 10 & 1 & 1 & 3 & 1 & 10 & & \\
\hline
\end{tabular}

A: João Pessoa; B: Dr. Cunha Lima; C: Solon de Lucena; D: Ministro José Américo de Almeida; E: Praça do Trabalho; F: Tenente Juvenal Espíndola; G: Pedro Freire; H: Simeão Patrício; I: Calçadão João Cardoso; Hab: habit; Her: herbaceous; Shr: shrub; Arb: arboreal; Org: origin; Exo: exotic; Nat: native.

Angelis \& Angelis Neto (2000), analyzing the vegetation of squares in Maringá (Paraná, Brazil), considered a well-preserved vegetation, found 62 tree, 42 shrub and 26 herbaceous species. Similarly, Lima Neto et al. (2007), studying green areas in the squares of Aracajú (Sergipe state, Brazil), identified 27 tree species.

João Pessoa (13 species) and Ministro José Américo de Almeida (10 species) squares and Calçadão João Cardoso (10 species) had the highest floristic richness, followed by Solon de Lucena square (six species). Dr. Cunha Lima and Pedro Freire squares accounted for three species each, and Tenente Juvenal Espíndola and Simeão Patrício for only one species each.

Fabaceae and Bignoniaceae were the most representative families in the public squares of Areia, with four species each. In the same way, as in forest areas in Brazil, Fabaceae is also very representative in urban squares (Kurihara et al., 2005). Fabaceae and Bignoniaceae were also the most frequent families in urban squares in Belém, Pará state, Brazil (Lindenmaier \& Santos, 2008) and in Tijuca neighborhood in Rio de Janeiro (Freitas et al., 2015).

In the municipality of Crato (Ceará state, Brazil), Santos et al. (2011) recorded 13 families, 15 genera 
and 18 tree species. Analyzing the tree planting of four squares in Tijuca in Rio de Janeiro, Freitas et al. (2015) found 36 species distributed in 30 genera and 14 families.

S. secundatum, found in João Pessoa, Solon de Lucena, Ministro José Américo de Almeida squares and in Calçadão João Cardoso, was the most common species, followed by F.benjamina, C. comosum, P. oleraceae e B. pauciflora, each one occurring in three squares. Regarding P. roebelenii, A. araucana, T. catappa, S. macranthera, L. camara, O. spiralis, each one was found in two squares. The other species were recorded in only one square.

Of the 11 species listed above as the most common ones, seven are exotic. According to Rocha et al. (2004), F. benjamina impairs the city road structure, damaging the pavement and causing conflicts with aerial grids, although it is widely used in urban tree planting (Cerqueira \& Silva 2013). Species like this, of medium or large size (Cemig, 1995), are inappropriate for tree planting and may affect telephone or electric cables in the very near future.

According to Biondi \& Macedo (2008), the increased planting of C. comosum in urban areas has been evident. These authors have warned that its incorrect management negatively interferes with the conservation and maintenance of remnants of the natural ecosystem because it is exotic and invasive. Omote et al. (2014) showed that $P$. roebelenii has the potential to become an exotic invasive species, since they observed several birds consuming its fruit and found many seedlings in their study area, evidencing the successful dispersion of this species.

According to Sanches (2009), T. catappa has a wide distribution characterized by the chiropterochory (dispersal by bats), which is very worrying because species considered established may become invasive when they are favored.

Only $37 \%$ of the species cultivated in the squares are native; $63 \%$ are exotic. These data are similar to those found by Santos et al. (2011) in a study carried out in the municipality of Crato, where they observed that $57.5 \%$ of the studied flora were exotic. According to Rezende \& Santos (2010), the use of exotic species in urban tree planting is quite common in Brazil, as it is observed in Maringá, which is one of the most forested cities in the country but has only $24.1 \%$ of native species.

The replacement of native flora by the exotic one has significantly changed the natural environment in urban centers. Moreover, the predominance of only one species or group of species may facilitate the spread of pests, which, currently, is very common in trees in urban environments. Paiva et al. (2004) state this is a consequence of the unawareness of the existence and potentials of native species, as well as due to the convenience of using species considered well adapted to different places.

João Pessoa square has the highest number of cultivated shrub and tree individuals (20 specimens), followed by Calçadão João Cardoso (17 specimens). The first one accounted for 13 young individuals and the second one only for adult individuals. In Ministro José Américo de Almeida square, there were 11 individuals; three of which were young. Pedro Freire and Solon de Lucena squares accounted for three and five individuals, respectively, all young. However, in Dr. Cunha Lima square, there were no tree/shrub individuals at any stage of development. About the other squares, each one had three adult individuals (Figure 1).

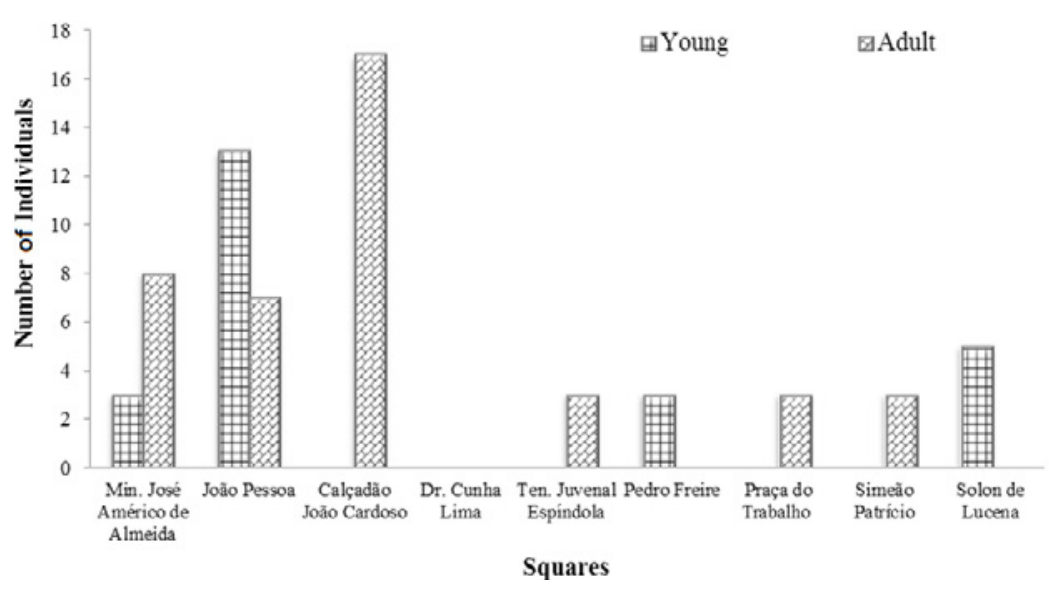

Figure 1. Representation of tree/shrub young and adult individuals in the public squares in the city of Areia, Paraíba, Brazil. 
João Pessoa square is the second largest one in the city of Areia; nevertheless, it accounts for only seven adult individuals, homogeneously distributed, so that more than $50 \%$ of its area is devoid of shade. In Solon de Lucena square, there were only herbaceous species and five young tree individuals.

According to Gomes \& Soares (2003), the presence of green areas in the cities becomes essential, since they are of extreme importance in the composition of the urban environment, either due to the visual contact they provide to the population or due to their biological-climatic role.

With regards to the height class, individuals higher than $6 \mathrm{~m}$ and $9.40 \mathrm{~m}$ are equally responsible for $50 \%$ of the contact of their aerial parts with the electric grid. Damage to square pavements is mainly caused by specimens with a height between $6.01 \mathrm{~m}$ and $9.40 \mathrm{~m}$ (62.5\%). These plants were also more susceptible to attack of plagues (12.5\%). Symptoms of diseases were mainly recorded in individuals higher than $9.40 \mathrm{~m}$ (Table 3).

Regarding the number of specimens, $P$. roebelenii was the most cultivated species, with eight and three individuals in João Pessoa and Ministro José Américo de Almeida squares, respectively, followed by R. oleracea, in
João Pessoa and Solon de Lucena squares (five specimens in each one), and B. forficata and T. catappa, in Calçadão João Cardoso (four specimens of each). However, $A$. araucana, P. diversifolium, B.pauciflora, L. lactescens and P. roebelenii were represented by three individuals each, in five different squares (Figure 2).

The planning of the frequency of species is extremely important in urban tree planting so that the distribution of individuals does not exceed the standard recommendations of tree planting manuals, which recommend that the number of individuals of each species should not exceed $10 \%$ to $15 \%$ of the total individuals of the population. This ensures a good distribution of species.

Considering the tree planting in the squares of the city of Areia, S. secundatum had the highest relative frequency (8.52\%), followed by R. oleracea, P. diversifolium, C. comosum and $F$. benjamina (6.38\% each) (Table 4 ). Regarding the distribution of $P$. diversifolium, this species was found only in Praça do Trabalho, which was represented only by this species. Similarly, the composition of Tenente Juvenal Espíndola and Pedro Freire squares consisted only of $F$. benjamina, thus evidencing a poor distribution of the species in these squares.

Table 3. Phytosanitary and deleterious damage characterization by height class of tree and shrub individuals in the public squares in the city of Areia, Paraíba, Brazil.

\begin{tabular}{lcccccc} 
Height class (m) & $\begin{array}{c}\text { Number of } \\
\text { individuals (\%) }\end{array}$ & $\begin{array}{c}\text { Disease } \\
(\%)\end{array}$ & $\begin{array}{c}\text { Plague } \\
(\%)\end{array}$ & $\begin{array}{c}\text { Mechanical } \\
\text { damage (\%) }\end{array}$ & $\begin{array}{c}\text { Damage to } \\
\text { the electric } \\
\text { grid }\end{array}$ & $\begin{array}{c}\text { Pavement } \\
\text { damage caused } \\
\text { by root (\%) }\end{array}$ \\
\hline $1.01-6.00$ & 69.23 & 6.67 & 4.44 & 33.33 & 8.89 & 15.56 \\
$6.01-9.40$ & 24.62 & 18.75 & 12.5 & 56.25 & 50.00 & 62.50 \\
$>9.40$ & 6.15 & 25.00 & - & 25.00 & 50.00 & - \\
\hline
\end{tabular}

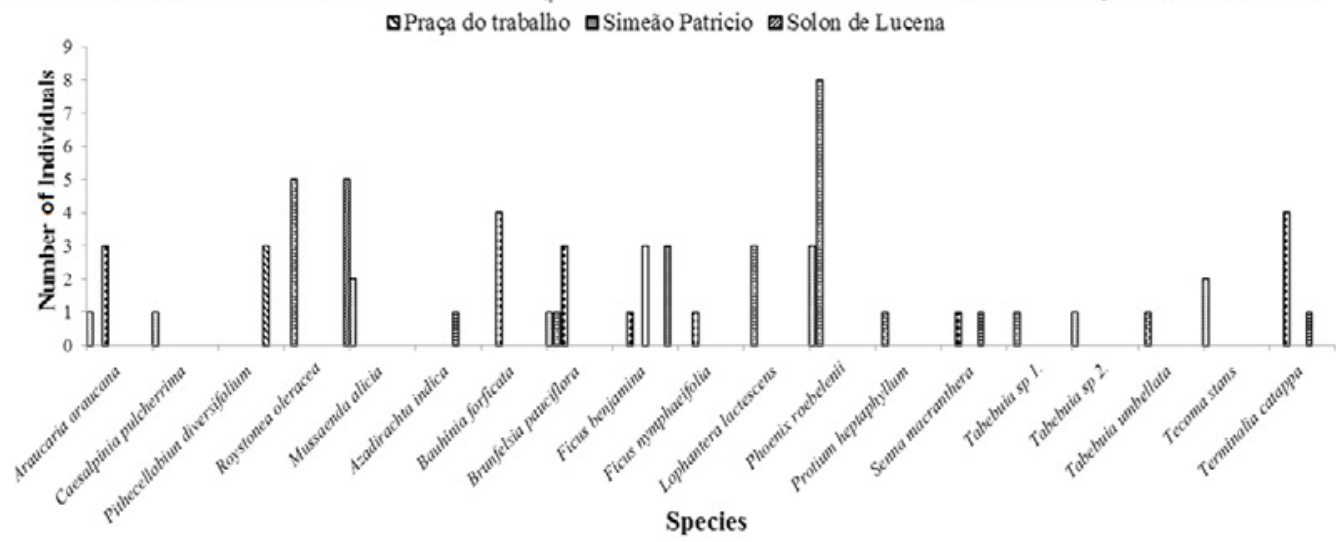

Figure 2. Representation of tree-shrub species in the public squares of Areia, Paraíba, Brazil. 
Concerning the toxic potential of the cultivated plants identified in the public squares of Areia, 28\% of the species contain toxic substances described by Lorenzi (1998; 2000; 2002), Lorenzi \& Matos (2002), Lorenzi \& Souza (2008) and Mattos et al. (2011). Thereby, these species need to be replaced or identified considering their toxic substances. Among these species, C. roseus, L. camarae and B. uniflora are amidst the 16 species that most cause intoxication in Brazil (Sinitox, 2009).

Toxic species such as $L$. camara were very frequent in squares of the municipality of Anápolis (Goiás, Brazil). Analyzing these public spaces, Perfeito et al. (2005) found that most of the cultivated species were toxic and that one square specifically comprised $53 \%$ of the toxic taxa. The practice of growing toxic plants in public environments is quite common in Brazil, due to the lack of urban planning; therefore, appropriate management is necessary.

Relating to the floristic similarity between the squares, the data showed a similarity only between Tenente Juvenal Espíndola and Simeão Patrício squares, which reached the maximum value (1) (Table 5) due to the presence of a single species in both squares.

From the data presented in the Jaccard's similarity matrix, 24 out of the 25 relationships showed dissimilarity (0), evidencing that there is neither standardization in the tree planting nor in the herbaceous cultivation in the city of Areia.

Table 4. Frequency of plant species occurring in the public squares of Areia, Paraíba Brazil.

\section{Species}

Araucaria araucana (Mol.) K. Koch.

\begin{tabular}{|c|c|c|}
\hline Araucaria araucana (Mol.) K. Koch. & 22.22 & 4.25 \\
\hline Azadirachta indica A. Juss & 11.11 & 2.13 \\
\hline Bauhinia forficata Link & 11.11 & 2.13 \\
\hline Brunfelsia pauciflora (Cham. \& Schltdl.) Benth. & 33.33 & 6.38 \\
\hline Caesalpinia pulcherrima (L.) Sw. & 11.11 & 2.13 \\
\hline Callistephus chinensis (L.) Ness & 11.11 & 2.13 \\
\hline Catharanthus roseus (L.) Don. & 22.22 & 4.25 \\
\hline Clorophytum comosum (Thunb.) Jacques & 33.33 & 6.38 \\
\hline Ficus benjamina $\mathrm{L}$. & 33.33 & 6.38 \\
\hline Ficus nymphaeifolia Miller & 11.11 & 2.13 \\
\hline Gaillardia $x$ grandiflora Van Hout. & 11.11 & 2.13 \\
\hline Lantana camara L. & 22.22 & 4.25 \\
\hline Lophantera lactescens Ducke & 11.11 & 2.13 \\
\hline Mussaenda alicia Hort. & 11.11 & 2.13 \\
\hline Oxalis spiiralis Ruiz \& Pav. ex G. Don & 22.22 & 4.25 \\
\hline Phoenix roebelenii O’Brien & 22.22 & 4.25 \\
\hline Pithecellobium diversifolium Benth. & 11.11 & 2.13 \\
\hline Portulaca oleraceae L. & 11.11 & 2.13 \\
\hline Protium heptaphyllum (Aubl.) March & 11.11 & 2.13 \\
\hline Rosa $x$ grandiflora Hort. & 11.11 & 2.13 \\
\hline Roystonea oleracea (Jacq.) Cook & 33.33 & 6.38 \\
\hline Senna macranthera (Dc. ex Collad.) H.S. Irwin \& Barnaby & 22.22 & 4.25 \\
\hline Solenostemon scutellari Oids & 11.11 & 2.13 \\
\hline Stenotaphrum secundatum (Walter) Kuntze & 44.44 & 8.52 \\
\hline
\end{tabular}

Absolute Frequency (\%) Relative Frequency (\%) 
Table 4. Continued...

\begin{tabular}{lcc} 
Species & Absolute Frequency (\%) & Relative Frequency (\%) \\
\hline Tabebuia sp 1. & 11.11 & 2.13 \\
Tabebuia sp 2. & 11.11 & 2.13 \\
Tabebuia umbellata (Sond.) Sandwith & 11.11 & 2.13 \\
Tecoma stans (L.) Juss. ex Kunth & 11.11 & 2.13 \\
Terminalia catappa L. & 22.22 & 4.25 \\
\hline
\end{tabular}

Table 5. Matrix of the floristic composition similarity represented by the Jaccard index values between different public squares in the city of Areia, Paraíba, Brazil.

\begin{tabular}{|c|c|c|c|c|c|c|c|c|c|}
\hline & A & B & C & D & $\mathbf{E}$ & $\mathbf{F}$ & G & $\mathbf{H}$ & I \\
\hline A & 1 & 0.666 & 0.187 & 0.210 & 0 & 0 & 0 & 0 & 0.050 \\
\hline B & & 1 & 0.285 & 0 & 0 & 0 & 0 & 0 & 0.100 \\
\hline C & & & 1 & 0.230 & 0 & 0 & 0 & 0 & 0 \\
\hline D & & & & 1 & 0 & 0 & 0 & 0 & 0.125 \\
\hline $\mathbf{E}$ & & & & & 1 & 0 & 0 & 0 & 0 \\
\hline $\mathbf{F}$ & & & & & & 1 & 0 & 1 & 0.125 \\
\hline G & & & & & & & 1 & 0 & 0.222 \\
\hline $\mathbf{H}$ & & & & & & & & 1 & 0.125 \\
\hline I & & & & & & & & & 1 \\
\hline
\end{tabular}

A: João Pessoa; B: Dr. Cunha Lima; C: Solon de Lucena; D: Ministro José Américo de Almeida; E: Praça do Trabalho; F: Tenente Juvenal Espíndola; G: Pedro Freire; H: Simeão Patrício; I: Calçadão João Cardoso.

\section{CONCLUSIONS}

The data evidences the need for a better planning of the floristic composition in the squares of Areia, since $63 \%$ of the 29 species classified are exotic and $28 \%$ contain toxic substances.

More attention should be paid to the selection of species for tree planting, considering that the most frequent species, such as F. benjamina (33.33\%), are responsible for damaging the pavement and the electric grid, as well as the presence of species considered as biological contaminants such as $C$. comosum, which also had a frequency of $33.33 \%$.

Tree and shrub individuals had more symptoms of diseases than pest infestation. Tenente Juvenal Espíndola and Simeão Patrício squares had maximum similarity (1).

These data contribute to improving the environmental quality and biodiversity and to the well-being and safety of the city population as well as of its visitors.

\section{ACKNOWLEDGEMENTS}

We are thankful to the Ecology and Botany Laboratory (LAEB/CDSA/UFCG) for the support in species identification and to the city hall of Areia forthe information given about the public squares.

\section{SUBMISSION STATUS}

Received: 8 Mar., 2017

Accepted: 24 Nov., 2018

\section{CORRESPONDENCE TO}

\section{Azenate Campos Gomes}

Universidade Federal da Paraíba (UFPB), Departamento de Ciências Farmacêuticas, Centro de Ciências da Saúde, Campus I Cidade Universitária, CEP 58033-455, João Pessoa, PB, Brasil e-mail: azenatecampos@gmail.com 


\section{REFERENCES}

Angelis BLD, Angelis Neto G. A vegetação e as praças na cidade de Maringá/PR. Acta Scientiarum 2000; 22(1): 1455-1461. 10.4025/actascitechnol.v22i0.3104

Angiosperm Phylogeny Group - APG. An update of the Angiosperm Phylogeny Group Classification for the orders and families of flowering plants: APG III. Botanical Journal of Linnean Society 2009; 161(2): 105-121. 10.1111/j.1095-8339.2009.00996.x

Barcellos A, Wojcikiewicz CR, Lubaszewski EA, Mazuchowski JZ, Conceição JR, Leal L et al. Manual para elaboração do plano municipal de arborização urbana. Curitiba: MPPR; 2012.

Biondi D, Macedo JHP. Plantas invasoras encontradas na área urbana de Curitiba (PR). Floresta 2008; 38(1): 129-144. 10.5380/rf.v38i1.11034

Brasil. Ministério da Agricultura. Levantamento exploratório: reconhecimento de solos do estado da Paraíba. Rio de Janeiro: Sudene; 1972.

Cemig. Manual de arborização. Belo Horizonte: Diretoria de Desenvolvimento do IEF; 1995.

Cerqueira MCR, Silva DAM. Análise do processo de arborização pública da cidade de SantanópolisBahia. Caderno Meio Ambiente e Sustentabilidade 2013; 2(1): 113-126.

Eckert NH, Mascaró JJ. Atuação da infraestrutura verde como qualificadora da ambiência urbana em centros consolidados: o caso de Passo Fundo RS. Revista de Arquitetura IMED 2015; 3(2): 168-176. 10.18256/2318-1109/arqimed.v3n2p168-176

Freitas WK, Pinheiro MAS, Abrahão LLF. Análise da arborização de quatro praças no Bairro da Tijuca, RJ, Brasil. Floresta e Ambiente 2015; 22(1): 23-31. 10.1590/2179-8087.025612

Gomes MAS, Soares BR. A vegetação nos centros urbanos: considerações sobre os espaços verdes em cidades médias brasileiras. Estudos Geográficos 2003; 1(1): 19-29.

Guzzo P, Carneiro RMA, Oliveira J. Cadastro municipal de espaços livres urbanos de Ribeirão Preto (SP): acesso público, índices e base para novos instrumentos e mecanismo de gestão. Revista da Sociedade Brasileira de Arborização Urbana 2006; 1(1): 19-30. 10.5380/revsbau.vli1.66437

Instituto Brasileiro de Geografia e Estatística - IBGE. IBGE Cidades. 2010 [cited 2014 May 14]. Available from: https://bit.ly/2Kwh3a9

Kurihara D, Imaña-Encinas J, Paula JE. Levantamento da arborização do campus da Universidade de Brasília. Cerne 2005; 11(2): 127-136.

Lima Neto EM, Resende WX, Sena MGD, Souza R. Análise das áreas verdes das praças do bairro centro e principais avenidas da cidade de Aracaju-SE. Revista da
Sociedade Brasileira de Arborização Urbana 2007; 2(1): 16-33. 10.5380/revsbau.v2i1.66559

Lindenmaier DS, Santos NO. Arborização urbana das praças de Cachoeira do Sul-RS-Brasil: fitogeografia, diversidade e índice de áreas verdes. Pesquisas, Botânica 2008; 59(1): 307-320.

Lira RS, Dantas CI, Cavalcanti FLM, Barros BJM, Lira MV, Carneiro TP. Diagnóstico paisagístico do Parque da Criança em Campina Grande, PB. Revista de Biologia e Ciências da Terra 2004; 4(1): 101-109.

Lorenzi H. Árvores brasileiras: manual de identificação e cultivo de plantas arbóreas nativas do Brasil. Nova Odessa: Plantarum; 1998.

Lorenzi H. Árvores brasileiras: manual de identificação e cultivo de plantas arbóreas nativas do Brasil. 4th ed. Nova Odessa: Plantarum; 2000.

Lorenzi H. Árvores brasileiras: manual de identificação e cultivo de plantas arbóreas nativas do Brasil. 4 th ed. Nova Odessa: Plantarum; 2002. v. 2.

Lorenzi H, Matos FJA. Plantas medicinais do Brasil: nativas e exóticas. Nova Odessa: Plantarum; 2002.

Lorenzi H, Souza HM. Plantas ornamentais do Brasil: arbustivas, herbáceas e trepadeiras. 4 th ed. Nova Odessa: Plantarum; 2008.

Marques AL, Silva JB, Silva DG. Refúgios úmidos do Semiárido: um estudo sobre o brejo de altitude de Areia-PB. Revista Geotemas 2014; 4(2): 17-31. 10.33237/geotemas.v4i2.1005

Mattos FJA, Lorenzi H, Santos LFL, Matos MEO, Silva MGV, Sousa MP. Plantas tóxicas: estudo de fitotoxicologia química de plantas brasileiras. São Paulo: Plantarum; 2011.

McKnight TL, Hess D. Climate zones and types: the Köppen system. In: McKnight TL, Hess D. Physical geography: a landscape appreciation. 6 th ed. Upper Saddle River: Prentice Hall; 2000. p. 200-201.

Mueller-Dombois D, Ellenberg H. Aims and methods of vegetation ecology. New York: John Willey \& Sons; 1974.

Omote T, Antunes AZ, Matsukuma CK. Comparação de aspectos fenológicos e de frugivoria entre a palmeira nativa Euterpe edulis Mart. e a palmeira exótica Phoenix roebelenii O'Brien (Arecaceae) no sudeste do Brasil. Revista Instituto Florestal 2014; 26(2): 169-181. 10.4322/rif.2014.013

Paiva PDO, Landgraf PRC, Rodrigues TM, Pedroso DDO, Oliveira Filho ATD, Gavilanes ML. Identificação e caracterização das espécies arbóreas do canteiro central da Universidade Federal de Lavras/MG. Ciência e Agrotecnologia 2004; 28(1): 515-519. 10.1590/S1413-70542004000300005

Perfeito P, Moreira PAS, Peixoto JC. Identificação de plantas tóxicas em praças públicas na Cidade de Anápolis, Goiás. In: Anais do Congresso de Iniciação 
Científica Universidade Estadual de Goiás; 2005; Goiânia. Goiânia: UEG; 2005. p. 1-8.

Pivetta KFL, Silva Filho DF. Arborização urbana: boletim acadêmico. Jaboticabal: Unesp; 2002.

Rezende TM, Santos DG. Avaliação quali-quantitativa da arborização das praças do bairro Jaraguá, Uberlândia-MG. Revista da Sociedade Brasileira de Arborização Urbana 2010; 5(2): 139-157. 10.5380/revsbau.v3i2.66347

Rocha RT, Leles PSS, Oliveira Neto SN. Arborização de vias públicas em Nova Iguaçu, RJ: o caso dos bairros Rancho Novo e Centro. Revista Árvore 2004; 28(4): 599-607. 10.1590/S0100-67622004000400014

Sanches JH. Potencial invasor do chapéu-de-sol (Terminalia catappa L.) em área de restinga [thesis]. Piracicaba: Escola
Superior de Agricultura “Luiz de Queiroz”, Universidade de São Paulo; 2009.

Santos ACB, Silva MAP, Souza RK. Levantamento florístico das espécies utilizadas na arborização de praças no município de Crato, CE. Caderno de Cultura e Ciência 2011; 10(1): 13-18.

Sistema Nacional de Informações Tóxico-Farmacológicas Sinitox. Plantas tóxicas no Brasil. 2009 [cited 2014 May 25]. Available from: https://bit.ly/2EYb8J9

Souza VC, Lorenzi H. Botânica sistêmica: guia ilustrado para identificação das famílias de Fanerógamas nativas e exóticas no Brasil, baseado no APG II. 2nd ed. Nova Odessa: Plantarum; 2018. 